\title{
Tissue Irradiation Facility
}

National Cancer Institute

\section{Source}

National Cancer Institute. Tissue Irradiation Facility. NCI Thesaurus. Code C133326.

A facility that irradiates body tissue products. 